This item was submitted to Loughborough's Research Repository by the author.

Items in Figshare are protected by copyright, with all rights reserved, unless otherwise indicated.

\title{
How to design fashion retail's virtual reality platforms
}

PLEASE CITE THE PUBLISHED VERSION

https://doi.org/10.1108/IJRDM-11-2019-0382

PUBLISHER

Emerald Publishing Limited

VERSION

AM (Accepted Manuscript)

PUBLISHER STATEMENT

This paper was accepted for publication in the journal International Journal of Retail \& Distribution

Management and the definitive published version is available at https://doi.org/10.1108/IJRDM-11-2019-0382.

\section{LICENCE}

CC BY-NC 4.0

\section{REPOSITORY RECORD}

Xue, Liangchao, Christopher J. Parker, and Cathryn Hart. 2020. "How to Design Fashion Retail's Virtual Reality Platforms". Loughborough University. https://hdl.handle.net/2134/12315311.v1. 


\section{PUBLISHING International Journal of Retail \& Distribution Manag}

\section{How To Design Fashion Retail's Virtual Reality Platforms}

\begin{tabular}{|r|l|}
\hline Journal: & International Journal of Retail \& Distribution Management \\
\hline Manuscript ID & IJRDM-11-2019-0382.R4 \\
\hline Manuscript Type: & Research Paper \\
\hline Keywords: & $\begin{array}{l}\text { Virtual Reality, V-Commerce, Shopping Experience, Retail Industry, } \\
\text { Design, User Experience }\end{array}$ \\
\hline
\end{tabular}

\section{SCHOLARONE ${ }^{\text {m }}$ \\ Manuscripts}




\section{How To Design Fashion Retail's Virtual Reality Platforms}

\section{Abstract:}

- Purpose - High street fashion retailing faces an uncertain future because of fluctuating consumer shopping habits. To revive fashion retailers, adopting disruptive technologies such as Virtual Reality becomes important to offer high valued consumer experiences. Yet v-commerce designers still lack sufficient guidance to create effective retail environments. This paper establishes the v-commerce experience that target fashion consumers desire and presents 13 specific design guidelines.

- Design/methodology/approach - 22 participants - 20 consumers and 2 VR developers - were interviewed regarding attitudes towards Virtual Reality, motivation to shop through v-commerce, and the influencing criteria that affect virtual environment perceptions.

- Findings - Consumers expect a vivid shopping environment, with authentic product features instead of the more common simulated environment. Hedonically motivated consumers are more open to v-commerce than utilitarian consumers and Consumers aged 18-34 regard interactivity, personalisation, and social networking as critical to offering a cost- efficient shopping experience.

- Research limitations/implications - This paper explored the ways vcommerce delivers creative experiences to facilitate consumer purchase behaviour, contributing to the high street's regeneration. Yet consumers have too high expectations of lifelike interaction in v-commerce, which is beyond contemporary VR's capabilities. Future research should focus on developing authenticity of $\mathrm{v}$-commerce environments, i.e. vivid interaction with product and people.

- Originality/value - This paper establishes the fundamental design rules for $v$-commerce platforms, enabling designers to create effective retail environments, sympathetic to the consumer's cognitive desires.

Keywords: Virtual Reality; V-Commerce; E-Commerce; Shopping Experience; Retail Industry; Design; User Experience; UX

\section{Introduction}

Fashion retailers assume they can, for the foreseeable future, attract consumers to high street stores through previously successful approaches and business models (Bilińska-Reformat et al., 2019). Yet electronic commerce (e-commerce) has changed consumer's shopping habits. Consumers moving from physical to online 
retail are having a significant impact on high street retail (Thakur, 2018). PwC (2017) shows that, on the British high street, there are fewer stores opening, but more store closures. At the same time, COVID-19's unprecedented impact on the global economy (Craven et al., 2020) is forcing consumers to become more reliant upon ecommerce retail. This is prominent in the fashion retail sector; embodying nonessential purchases.

A declining high street sector impacts the entire fashion retail sector. Consumers switching to e-commerce affects physical sales or even retailers' overall profit when online sales are below expectations. An uncertain economic environment is also impacting shopping habits. Retail is moving from a traditional product-centred approach to a customer - or service - centred perspective (Pantano et al., 2018). Consumers show a growing preference for experience over the acquisition of 'stuff' (Brown and Lubelczyk, 2018). Consumers demand more experience from brands at the exact time they are losing physical experiences in the high street.

Predictions abound about the demise of physical stores, how disruption technologies such as virtual reality, robots, and artificial intelligence $(\mathrm{Al})$ replace human labour (Huang and Rust, 2018). For example, robots can assemble IKEA furniture without human help (Burdick, 2018). These technology developments are disrupting the marketplace. The service industry, as a result, faces enormous challenges and opportunities as consumers' experiences occur at the intersection of each consumer's digital, physical, and social domain.

Major fashion companies are following the technological trend, either developing their own tools or collaborate with technology corporations. ASOS, for instance, has developed a 'Style Matching' tool and expects to boost sales growth of 30-35 percent. Although many companies are racing to innovate in this area, none have yet gained significant user acceptance. It is obvious to see which tools will succeed and how these tools fit into the everyday shopping experience for daily shoppers. Once the daily shoppers accept a solution, that solution will diffuse among retailers (Amed et al., 2018).

Retailers are facing in increasing array of complex and expensive technologies. How brands create consumer value using technology will, thus, determine the market's size (Pantano et al., 2018). Futurists assume virtual reality retail (v-commerce) to be retail's next disruptive technology (Wang, 2016), reviving high street fashion stores and delivering exceptional online experiences. V-commerce can also increase fashion retailers' competitive advantage for anyone who can tap into the consumers' shopping behaviours. Yet, despite v-commerce being heralded for over a decade (Arakji and Lang, 2008; The VR/AR Association, 2017), v-commerce has yet to influence the consumer's shopping behaviours.

V-commerce's lack of disruption is because of the limited agreement regarding the optimal consumer-centred experiences, how experiences translates into effective consumer-centred designs, and how designs translates into effective consumer- 
centred virtual stores (Xue et al., 2018). Without understanding the format consumers desire from v-commerce interactions, virtual retail will remain an interesting toy of marketing (e.g. Hope Allwood, 2016) instead of a pivotal driver of sales (Bonetti et al., 2018). To meet consumers' expectations, and understand how v-commerce can impact high street retail, researchers must determine how consumers will use v-commerce compared to visiting physical shops (Chaffey, 2017; Chen and Cheng, 2009; Kim, 2002).

To accomplish this goal, retailers and designers must understand how v-commerce can meet fashion retail's consumers desires (Wang et al., 2011). Yet designers do not have the experience or guidelines to develop effective, interactive and usable VR environments to drive retail sales (Xue et al., 2018). Retailers, therefore, strive to fill this gap by meeting the consumer's increasing and diversified demands for greater efficiency and productivity.

E-commerce is entering the fourth generation, and consumer demand will continue to evolve with time. The influencing criteria that affect the consumer's engagement with v-commerce shopping are ill-defined (Papagiannidis et al., 2017; Speicher et al., 2017; Zhou, 2007). Retailers therefore need to develop effective and provocative vcommerce platforms.

Retailers are grappling with designing store format and operations, as they contemplate how e-commerce impacts their traditional business models (Tode, 2017). Designers can create retail environments to produce specific affective responses in customers, improving their purchase intention (Ballantine, 2005). Yet designers disagree with how to create optimal experiences or motivate purchases (Xue et al., 2018). Retailers, therefore, must collaborate with designers to create a vcommerce environment that encourages buying behaviours.

This paper aims to establish the format of v-commerce experience that fashion consumers best respond to. To address this research aim, this study needs to understand:

1. Consumer response (attitudes and motivations) to v-commerce, in order to understand consumers' changing demands for shopping experiences from physical to virtual.

2. The influencing criteria that affect consumers' perception when developing vcommerce environments or retailing in order to develop more effective and emotional seductive v-commerce platforms.

3. How to create an effective v-commerce environment in to allow designers to create a virtual environment that encourages fashion buying behaviours.

In answering these research questions, this study interviewed 20 of high street fashion's target consumers and two VR developers. This study establishes that consumers expect a vivid shopping environment, with authentic product features, over the common simulated environment. Hedonically motivated consumers are more open to v-commerce than utilitarian consumers, and consumers aged 18-34 
regard interactivity, personalisation, and social networking as critical to offering that a cost-efficiency shopping experience. This study concludes by proposing 13 design principles for creating v-commerce environments that meet consumer's desires.

\section{Background Theory}

\subsection{E-Commerce and V-Commerce}

E-commerce offers consumers opportunities to experience a seamless omni-channel retailing or multichannel retailing (Brynjolfsson et al., 2013). It offers a wide range of choice selections, convenience, competitive prices, personal attention, rich information including product reviews to boost online sales (Grewal et al., 2004; Holte, 2013; Kang, 2017; Tseng and Yazdanifar, 2015; Zhou, 2007). The convenience consumers perceive also impacts on their online shopping activities (Eastin, 2002; Elliot and Fowell, 2000).

Through e-commerce, shoppers cannot experience the atmosphere of a store, interact with salespeople, or seek sensory stimulation. Retailers are trying to moderate the lack of atmospherics' impact to mitigate negative purchase impacts (Escobar-Rodríguez and Bonsón-Fernández, 2017). In online retail environments, designers must apply interactivity to meet the customer's relational expectations (Demangeot and Broderick, 2006).

V-commerce is different to e-commerce, it represents an emerging shopping channel. In this virtual 3D environment offered by v-commerce, functionality and interactivity can be enhanced, and cover the e-commerce lack of direct interaction with product and people (Vrechopoulos et al., 2009; Walsh, 2002). In addition, vcommerce increases sensory depth compared to e-commerce, as it can transmit more detailed 3D images than 2D static images (Klein, 2003), which enable consumers to browse more diverse items and have more realistic and engaging experiences (Kang, 2017).

Compared to traditional online shopping, this technology shows great potential in providing entertainment, advanced customer experiences, and enhanced consumer trust (Papadopoulou, 2007) because of its immersive characteristics (Forni and Meulen, 2016; Garnier and Poncin, 2010).

To compare Virtual Reality (VR) with Augmented Reality (AR), Virtual Reality is complete immersion in a virtual world with virtual objects, see Table 1. Whereas AR is more appropriate for physical stores than VR, since it permits the overlap of virtual elements in the physical worlds, which enable consumers to test several items without trying them on (Caboni and Hagberg, 2019).

[INSERT TABLE 1] 


\subsection{Consumer Response towards V-Commerce}

Shoppers desire a superior level of service (Chevalier and Ivory, 2003). Online consumers still expect to explore e-commerce environments, even though they are virtual (Demangeot and Broderick, 2010). Current research states customers have a positive attitude toward AR and VR as they are emerging technologies that produce a novelty effect (Meißner et al., 2018; Yim et al., 2017), create efficiency and shopping value (Dacko, 2016; Papadopoulou, 2007), and enhance the consumer's shopping motivations (Altarteer et al., 2013).

According to a current market study, $90 \%$ of the UK consumers shop online (Carroll, 2019). Among them, $65 \%$ of consumers are considering changing their traditional shopping by such capabilities (Skeldon, 2020). However, VR needs a stronger business model and technical improvements, since customers realise that the virtual environment is still in a developing stage (Papagiannidis et al., 2017). Such positive consumer attitude towards $v$-commerce confirms a need to understand the consumers' value of v-commerce in this paper.

Consumers can compare or choose products while staying at home through vcommerce platforms. In this way, it reduces time and effort while shopping. Entertainment, fun, and enjoyment are, however, the primary attractions of 3D modelling product to customers (Algharabat et al., 2017; Kim and Forsythe, 2007). Further, VR also enhances the consumer's shopping motivation. This is driven by $3 \mathrm{D}$ visualisation's capability to illuminate the aesthetic, and functional, aspects of products that the consumer considers purchasing (Altarteer et al., 2013).

\subsection{Influencing Criteria Affecting Consumer's Perception of V-Commerce}

Most consumers have no experience with v-commerce. Investigating what consumers want is, therefore, challenging. Newhagen et al. (1995) argues that individuals cannot experience interactivity without prior incentive to engage with an interactive environment beforehand. This study must, therefore, understand consumer motivation.

Consumers' shopping behaviours differ based on whether their shopping motivations are hedonic or utilitarian (Wolfinbarger and Gilly, 2001), as Parker and Wang (2016) categorise in Table 2, utilitarian values refer to the purchases' convenience, the goods' availability, and the time and place of shopping (Singhavolakul et al., 2011). Hedonic values refer to the emotional state that develop from the experience, and may involve all elements (e.g. background, colour, light, and other design elements) that contribute to pleasurable feelings (Coursaris et al., 2008; Al Qeisi and AlAbdallah, 2014; Vila and Kuster, 2011). This study determines hedonic and utilitarian motivation's value for $\mathrm{v}$-commerce.

[INSERT TABLE 2] 
Immersion in a virtual world affects consumers' desires and product perception (Trabelsi-Zoghlami and Touzani, 2019). They become more demanding, asking for more customisation in their shopping experiences which retailers must take into account (Fornerino et al., 2008). Xue et al. (2018) showed that retailers must understand those factors that affect consumer perceptions in v-commerce. These are classified into comfort, content, functionality, media richness, perceived value, social networking, and consumer experience. This study considers these factors when developing a v-commerce environment.

\subsection{Designing Effective V-Commerce Environments}

The Virtual Reality medium offers a novel way to experience product and shopping environments that combine the advantages of both offline and online shopping. Papadopoulou (2007) shows that e-commerce can embrace VR with functions tailored to shopping activities. V-commerce's functions include product recommendations, product display, product information, and purchase functions. User interface and design, however, warrants a deeper consumer analysis (Speicher et al., 2017), otherwise consumer satisfaction will decrease because of information overload in v-commerce. Exploring, and comparing, v-commerce's different layouts and representations would provide important insights to designing effective retail environments.

Researchers are struggling with how to create effective VR marketplaces. Park et al. (2018) revealed that earlier Computer Simulated Retail Experience (CSRE) research excludes VR immersive systems. Most CSRE papers are empirical studies, with over $80 \%$ using non-immersive systems. In these non-immersive systems, seated participants must look at a high-resolution screen and use a keyboard and mouse. The studies, therefore, do not replicate the VR experience. Even with these limited studies, no research investigates VR in apparel shops. In apparel shops, the layout and visual merchandising is different to grocery stores because of the product's texture and type and fashion retail's customer journey.

Previous studies were aiming to investigate in the VR market the functionality required by the user interface and its influence on shopping behaviour (Kang, 2017). Altarteerx et al. (2013) explore human computer interaction's impact on customer experience in e-commerce interfaces. This application aims to increase ecommerce's volume and speed by improving the customers' experience through precise, photorealistic, and interactive 3D objects. The authenticity of visual information is to increase consumers' trust in online information when buying highcost luxury goods. To achieve this paper's aims, therefore, requires design, computer science, marketing, and human computer interaction approaches (Bonetti et al., 2018). 


\section{Methods}

This study uses a qualitative method as the research questions require more indepth than what can provide. To increase the insights, this study interviewed 20 consumers and two VR developers before conducting thematic analysis on their transcripts.

\subsection{Setting and Sampling}

The study focuses on British male and female consumers aged 18-45. 18-34-yearold consumers are the most receptive audience to VR, irrespective of Gender (Nielsen, 2016). This sample is $27 \%$ of the global high street fashion market by 2020, with a high propensity to adopt emerging technology (Niemeier et al., 2013). To generalise the data, 35-45 aged respondents have been interviewed for comparison. This paper also included VR developers to gain an industry-centred perspective.

This research invited 22 participants to this study by purposive sampling, ensuring a suitable spread of participants across the sampling frame; comprising 20 consumers and two VR developers. Gaskin et al. (2010) recommends 10-30 interviews can produce 75-150 statements from participants. Nielsen (2000) suggests that there will be less new findings after interviewing 15 participants. This study applies qualitative methods to achieve deeper emotional insight than widespread surveys offer. The semi-structured interviews occurred between August and October 2018.

\subsection{Data Collection Methods}

\subsubsection{Consumer Response}

To understand the consumer's attitudes towards e-shopping acceptance (technology acceptance, usefulness, ease of use, enjoyment, and trust) and motivations (hedonic and utilitarian) towards v-commerce, will enable retailers to respond to the consumers' needs and enhance competitiveness. Semi-structured interviews took place in London, Manchester, and Sheffield; preferring universities, coffee shops, and shopping centres.

The interview first confirmed the age of participants before showing them two VR shopping videos featuring ASOS (Figure 1) and Alibaba (Figure 2) to capture their response to various questions:

\section{[INSERT FIGURE 1]}

Figure 1. ASOS: Trillenium Demo App (Vida 3D, 2015)

Trillenium is a leading developer of 3D VR store for retailers, who conducted trials with ASOS. This video shows an initial user interface of virtual shopping environment. 
Figure 2. Buy+ The first complete VR shopping experience (Alibaba Group, 2016)

Alibaba released a video that shows the shopping process of a consumer wearing a VR headset and entering a Macy's store to purchase a handbag in $360^{\circ}$ environment.

Participants can better understand VR shopping through these two videos. The researcher can then observe how participants react to both forms of virtual shopping and explore, in depth, their desires/preferences and the factors that influence their perceptions toward virtual shopping.

\subsubsection{Influencing Criteria}

To understand the influencing criteria that affect consumers' perception when developing a v-commerce environment for retailing, authors suggest the need for more effective and emotional seductive platforms. Xue et al. (2018) identify the factors that influence the consumer's perception as:

- Comfort

- Content (environment, information, product display, and product features)

- Functionality (accessibility, interactivity, personalised service, and vividness)

- Media richness

- Perceived value (convenience, cost, and trust)

- Social networking

- User experience (physical presence, product involvement, and product perception)

Basing the interviews on Xue et al.'s (2018) influencing factors allows the pursuit of experience design based insights during the investigation.

\subsubsection{Creating Effective V-Commerce}

To understand how to create v-commerce environments that encourage buying, this study applied semi-structured interviews. First, the study combines the consumer's view of the VR shopping with environments they desire to experience. Second, this research interviewed two VR developers to understand the desires of retailers and consumers to establish if $\mathrm{V}$-commerce can realise their vision. The lead researcher transcribed all interview recordings.

\subsection{Data Analysis}

This study analysed full transcripts with NVivo 11 (QSR, 2017), with thematic analysis aiding a deeper insight into the data than otherwise possible. Through thematic analysis, the study gained insights into consumer reactions to VR within Vcommerce, alongside their desires/preferences and the factors that influence their perceptions toward v-commerce. 


\section{Results and Analysis}

\subsection{Consumer Response to V-Commerce}

Table 3 presents the key themes derived from thematic analysis of consumers' attitude and motivation toward v-commerce.

\section{[INSERT TABLE 3]}

\subsubsection{Attitude Towards V-Commerce and Barriers}

The younger generation (aged 18-25) are v-commerce's main adopters. As shown in Table 3, 94\% of participants in the age group of 18-34 were familiar with VR. Those same participants showed great potential to experience $V R$, as the technology can offer many benefits for them that match their interest in innovative technology. In contrast, $40 \%$ of participants aged 35 to 45 showed negative attitudes about adopting v-commerce. This is because of the challenge of altering existing shopping modes and behaviours compared to a younger audience. Methods for change include 3D environment emulation, sensitive and interactive home shopping, and a unique check-out procedure.

"I like to be able to feel things and hold them. And there are a lot of aspects of virtual shopping that I wouldn't feel comfortable unless I could experience and feel the product in person." (participant 5).

Hedonic consumers are more open to accept v-commerce than utilitarian consumers. Participant 19 (35-45 age group) highlighted this point:

"I am not fully convinced to partake in VR shopping. It gives a view of what the shop would ordinarily look like aesthetically, but is that a plus for me to buy the product? No." (participant 19).

Half of the participants worried about being unable to afford VR goggles; costing around $£ 399$ (Oculus, 2020). 74\% participants expect the price of a headset should be under $£ 200$, while $21 \%$ proposed that retailers need to take the responsibility for the cost of v-commerce; see Figure 3.

\section{[INSERT FIGURE 3]}

Figure 3. The percentage of participants based on a VR headset's accepted cost

\subsubsection{Motivation Towards V-Commerce}

14 participants expressed their desire to try VR shopping because of the novelty effect.

"It is quite interesting as a new technology, I want to try something new..., to test the new shopping experience" (participant 16).

Amongst them, $50 \%$ of participants desire to try VR as an experiment, but not for long-term use. 
"I guess, just for the fun experience of it, to try it out, but otherwise l'm pretty happy with current in-store and online shopping." (participant 5)

If $\mathrm{v}$-commerce cannot offer additional value to the experience than current shopping channels, consumers' motivation toward v-commerce will decrease.

\subsection{The Influencing Criteria that Affect Consumers' Perception when Developing $V$-commerce for Retailing}

Table 4 presents the key themes derived from thematic analysis of consumers' influencing criteria towards v-commerce.

\section{[INSERT TABLE 4]}

\subsubsection{Convenience and Accessibility}

$70 \%$ of participants perceived convenience in v-commerce as a top priority, helping consumers to save effort and make purchase decisions.

"Convenience should be very important, priority. You are asking users to learn a new skill, so it should be very convenient and provide a great experience for them to keep using it. Otherwise they may just want to feel fresh for the moment." (participant 18).

No participants considered time saving as an outcome from v-commerce. This is interesting because consumers will spend more time to browse around or to interact with distinct features, like physical shopping.

\subsubsection{Authenticity (environment and product feature)}

18 participants wish to experience v-commerce as lifelike interactions, otherwise there will be a negative impact on consumer trust in v-commerce.

"... the product presented in the VR should be exactly same with the physical product that would increase the consumer's product perception and make VR shopping more reliable." (participant 6).

Such interactions are outside contemporary VR's capabilities, being restricted to $360^{\circ}$ video and preventing interactivity. Consumers have too high expectations of vcommerce, with current technology unable to satisfy their desires.

\subsubsection{Interactivity}

\subsubsection{Product Interaction:}

$75 \%$ of participants believe interacting with products will improve product perception and provide a better understanding of the products, as long as the technology is mature. 
"The interactivity should be smooth and active. If it's very clumsy and hard to use, I can easily hate it. But if it's very responsive and easy to use, I will feel very much engaged and my perception may change positively...." (participant 12).

\subsubsection{Social Interaction:}

19 participants propose that the role of sales assistant in VR is very helpful and interesting.

"For Amazon, there is no one can interact with customers (live chat), VR could do this. A real or Al sales assistant both would improve the online shopping experience. Disabled people (deaf), would be helpful to have [a] live chat [feature]. VR can meet various customer groups' needs." (participant 8).

19 participants also regard the social dimension as part of their entertainment. This is because social dimensions are not VR's focus. Yet consumers report surprise when meeting other consumers inside virtual environments. Consumers also feel positive about separate shopping sessions for friends and family, but joint virtual shopping sessions.

\subsubsection{Personalisation}

\subsubsection{Personalised interface:}

Pairing shopping behaviours should improve their shopping experience and makes v-commerce more attractive. $15 \%$ of participants, however, mentioned they want to keep privacy sometimes during online shopping, and a few of them become more introverted when shopping, avoiding social distraction for some shopping occasions.

"If I use VR, a big part of it because I want to shop alone sometime..., I prefer to share the product information rather than shopping with friends. The only interactivity I require is the product itself and sales assistant." (participant 10).

\subsubsection{Personalised Service:}

$70 \%$ of participants said they are keen to get personalised service through recommending new garments or matching items from the consumer's preference:

"I hope to receive personal advice from [a] sales assistant, the sales assistant will provide further product or alternatives information if the consumer has been focused on one product for a long time." (participant 18).

\subsection{Creating Effective V-Commerce Environments}

\subsubsection{Entertainment}

$45 \%$ of participants feel excited about shopping in a unique environment through vcommerce, because a unique journey creates enjoyable experiences.

"It would be very cool and interesting if I can shop the stores which I have never been before". (Participant 10). 
"the content in VR shopping environment is built virtual, so I will be attracted by those wild and novelty ideas." (participant 20).

$50 \%$ of participants regard adventure shopping is unnecessary. This is because they cannot imagine shopping as an experience, or only have utilitarian shopping motivations.

\subsubsection{Virtual Sales Assistant (Intelligent Assistant System)}

All participants believed that human service is much more reliable than the limited reply from artificial intelligence $(\mathrm{Al})$ that can only answer few certain questions:

"I'm looking forward to seeing interaction with the sales assistant and it can respond to me emotionally.... Until VR can offer these advantages from the comfort of my home, I would stick to laptop online shopping". (participant 6).

Consumers often only know about single-line products, and will seek more information about a similar product within different prices and brands. Consumers can, thus, benefit from the function 'guess what you like' to filter the most suitable products.

\subsubsection{Personalised Interface - Hedonic or Utilitarian:}

A consumer's method of shopping varies depending on whether their search motivation is for fun or efficiency. The motivations are utilitarian or hedonic.

"Maybe a lot of people like the feeling of shopping. But I think you need to provide two kinds of shopping mode to both utilitarian and hedonic consumers." (participant 1).

This implies that if the consumers are visiting shops for specific items (role shopping) they will not seek to use v-commerce.

\section{Discussion}

\subsection{Consumer Response (Attitudes and Motivations) of V-Commerce}

Table 3 shows that younger generation consumers responded more positively to vcommerce than older consumers. The older participants' group find it is difficult to embrace such unknown technology because of the changing shopping habits.

Consumers have a limited awareness regarding VR and therefore require more time to accept the technology. The consumers with lower levels of technology skill and familiarity are an issue.

The result is consistent with Nielsen's (2016) research where participants aged 18 to 34 show an interest in VR for supporting purchasing decisions, including interactive tools for comparing, searching, testing, and trying products (Pantano and Viassone, 2014). Given that novelty effect depletes over time, v-commerce's effectiveness is limited in generating positive consumer evaluations. 
The study also found that consumers are not convinced in v-commerce's use despite being open to trying the technology; especially for participants aged 35-45. Once vcommerce loses its appeal, or unique value, there will be no drive to motivate consumers to use v-commerce. Consumers will quit the virtual world.

V-commerce doesn't improve the quality of products and/or decrease their price. To keep v-commerce attractive, retailers must consider how to provide extra value to products, services, and distinctive experience through VR platforms. Retailers may, for example, offer loyal consumers VR accessories as gifts or loan items when they purchase. This will reduce consumer perceptions of price and have a positive impact on the consumer's attitude toward v-commerce. To reduce technology acceptance barriers, VR developers should focus on developing human factors theory for in VR store design (social dimension, eye-tracking, and disadvantages of consumers' considerations). Developing human factor theory will reduce the need to change older and disadvantaged consumers shopping behaviours.

\subsection{The Influencing Criteria s that Affect Consumers' Perception when Developing V-Commerce for Retailing}

V-commerce's convenience is the most influential factor for home consumers in their desire to adopt the technology. None of the participants feel virtual shopping can help them save time when shopping. V-commerce's low level of trust is because vcommerce cannot - currently - provide the consumer with multisensory experience of a product comparable to physical retail. V-commerce is, therefore, in a weaker position.

Participants expect to improve the credibility of v-commerce by gaining vivid interactions with products to enhance their product perception. Because of consumers' diverse demands, the interface of v-commerce can offer different modes to satisfy both hedonic and utilitarian consumers from personalised entertainment functions. Such functions may include social interaction, adventure shopping experience, background music, and lighting (Munir et al., 2016). This can build the consumer's trust in v-commerce (Chesney et al., 2017). Consumers also expect helpful virtual assistants to provide more specific and detailed product information to satisfy a variety of personal needs (e.g. personal service) during their shopping activities.

Participants feel excited to interact with their friends, family, or the strangers in the virtual world. Further, through virtual communities, consumers can post articles, reviews, and product recommendations with feedback from other consumers, which encourages consumer trust (Rese et al., 2014). Yet some participants mentioned they want privacy during online shopping, some even prefer to shop alone. These outcomes are interesting since social shopping motivations associate with a greater preference for e-commerce engagement (Parker and Wenyu, 2019). Personalised interfaces therefore become essential. 


\subsection{What Makes an Effective V-Commerce Environment?}

The findings suggest the optimal v-commerce experience and how to create an efficient v-commerce interface to enhance consumer buying behaviour is ill-defined. A deeper consumer analysis is warranted.

To meet different shopping motivations, v-commerce designers must offer simple purchase procedures, efficient search engines, handy features: guidance system, product recommendation, and product comparison (Yoo et al., 2010). These features will direct utilitarian consumers to the item they need and will positively impact their perception towards v-commerce. V-commerce designers should, therefore, incorporate entertainment and social interaction elements to captivate hedonic consumers (Parker and Wenyu, 2019).

The participants are looking forward to interacting with salespeople, similar to physical retail environments that elicit more of an emotional response. $\mathrm{V}$-commerce designers must, therefore, deliver a more resourceful help system in virtual reality to answer consumers' queries, needs, build human contact, and promote trust. Designers can, for example, incorporate 'shopping time' with the seller. In these scenarios, consumers interact with a physical salesperson to resolve issues that virtual assistants cannot deliver. This personal shopping experience will enable consumers to feel the service is tailored to them; providing personal meaning.

Although AR and VR technologies are becoming well known among consumers, there remains the significant issue of lack of high-quality content, and the gap between the price the consumer pays and the experience they receive. This study suggests v-commerce's content design should surpass that of physical stores, enabling consumers to experience events they couldn't achieve in the real-world retail environment. Consumers may, for example, visit stores around the world or shops divorced from the routine physical shopping location. V-commerce can create and emulate travelling or learning experiences, combined with shopping transactions. Consumer's time and energy costs will reduce in the entire shopping process. When VR product quality improves, along with the price of mass production, these technologies will become as necessary to the consumer as the smartphone.

\section{Design Requirements for VR/ AR Interfaces}

Based on the study results, to create a successful VR/ AR interface in fashion retail, the v-commerce designer should follow the factors presented in Table 5. While some elements reflect the Neilsen and Molich's (1990) heuristics, the design recommendations advance this accepted approach to system usability, by offering specifics designed to encourage fashion based business improvements. For example, \#12 maps to Neilsen and Molich's (1990) suggestion to match the system to the real world. Whereas the authors omitted personalised shopping environments 
based on shopping motivations (\#7), surpassing physical store possibilities (\#11), and the embrace of social dimensions (\#13).

\section{[INSERT TABLE 5]}

\section{Conclusion}

This paper aimed to explore the ways v-commerce delivers creative experiences to facilitate consumer purchase behaviour. In addressing this aim, this study proves hedonic consumers, and 18 to 34 aged consumers, are the most responsive to vcommerce as a future retail solution. Older consumers are, however, less receptive because of their more established purchasing habits that must first be addressed. Irrespective of the consumer group, the study proves that consumers worry about vcommerce's cost (i.e. VR headsets and high-powered computers). Among the influencing criteria of v-commerce, convenience is the most important factor for the online shopper to adopt VR. However, consumers' demands are diverse. Retailers offering personalised entertainment functions will satisfy utilitarian and hedonic consumers, leading to greater consumer engagement and - ultimately - sales. The lack of multisensory experience of VR causes consumers' low level of credibility towards v-commerce. Hence, offering vivid interactions with product and people will improve consumers enhance consumers' trust.

At a theoretical level, this paper defines the factors that affect the consumer's engagement with v-commerce. These factors are convenience and accessibility, environment and product authenticity, interactivity, and personalisation. This study closes the gap in the knowledge relating to v-commerce design by offering 13 specific design guidelines. To create effective environments, a v-commerce platform must include high-quality content that goes beyond shopping activities (e.g. learning and travelling etc.) to enhance consumer engagement.

From a managerial level, this paper recommends retailers emphasise the consumers' diverse needs to improve the overall shopping experience. Retailers can achieve this by considering the influencing criteria mentioned above. Consumers desires are, however, hard to meet with virtual reality's current technological state. V-commerce designers should, therefore, involve interdisciplinary thinking/knowledge when designing the content outside the normal guidelines of a physical store. Freed from the constraints of existing shopping activities, retail experiences should be hedonic, but not extreme as to alienate key consumer groups who desire new expressive experiences within their own comfort zone. While each vcommerce design is unique, the data-driven insights offer v-commerce designers a starting point to create experiences suitable for fashion retail's target consumers.

Under COVID-19's severe impact, consumers online shopping has transformed from a Web 2.0 luxury to a social necessity. Having e-commerce as a social necessity shift consumers from physical shopping to e-commerce. Retailers must embrace, and develop, e-commerce at a level unseen since 2002's Dot-com bubble implosion. 
This is an opportunity for retailers to disrupt existing consumption patterns and open a new era of online shopping. V-commerce has uncapitalised upon potential to captivate consumers and dominate the evolving online domain. Consumers may access the virtual communities (social-distancing) to share their lifestyle and product ideas instead of posting tedious product reviews. This will enhance consumers' sense of virtual community and satisfy vulnerable groups' social and shopping needs.

\subsection{Limitations and Future Research}

The focus on future-gazing, rather than current technology's experience, limits this study. Showing participants concept v-commerce videos does, however, encourage their imagination to use and explore possibilities beyond existing design. This limitation creates intriguing research opportunities. Researchers can, for example, empirically test consumers' response to v-commerce interfaces developed in line with this paper's v-commerce design requirements. This paper also focuses on vcommerce's consumer requirements and desires. Further exploration of systems, products, and service requirements will expand upon the results. Through such research, retailers and designers will gain a greater insight into developing effective and emotionally seductive v-commerce platforms grounded in the human centred design requirements. Future research should therefore focus on developing vcommerce environments to capitalise upon the emotional and functional outcomes of this study within realistic retail environments.

\section{References}

Algharabat, R., Abdallah, A., Rana, N.P. and Dwivedi, Y.K. (2017), "Three dimensional product presentation quality antecedents and their consequences for online retailers: The moderating role of virtual product experience", Journal of Retailing and Consumer Services, Elsevier Ltd, Vol. 36 No. December 2016, pp. 203-217.

Alibaba Group. (2016), "Buy+ The First Complete VR Shopping Experience YouTube", Youtube, available at: https://www.youtube.com/watch?v=HcKRBKlilg (accessed 9 July 2019).

Altarteer, S., Charissis, V., Harrison, D. and Chan, W. (2013), "Interactive virtual reality shopping and the impact in luxury brands", International Conference on Virtual, Augmented and Mixed Reality, Springer Berlin Heidelberg, pp. 221-230.

Altarteer, S., Vassilis, C., Harrison, D. and Chan, W. (2016), "Product customisation: virtual reality and new opportunities for luxury brands online trading", Proceedings of the 21st International Conference on Web3d Technology, ACM, pp. 173-174.

Amed, I., Berg, A., Balchandani, A., Beltrami, M., Andersson, J., Hendrich, S., Young, R., et al. (2018), The State of Fashion 2019, McKinsey \& Company\&Company, available at:https://doi.org/10.1163/156853010X510807. 
Arakji, R. and Lang, K. (2008), "Avatar business value analysis: a method for the evaluation of business value creation in virtual commerce", Journal of Economic Commerce Research, pp. 1-14.

Babin, B.J., Darden, W.R. and Griffin, M. (1994), "Work and/or Fun: Measuring Hedonic and Utilitarian Shopping Value", Journal of Consumer Research, Vol. 20 No. 4, pp. 644-656.

Ballantine, P. (2005), "Effects of interactivity and product information on consumer satisfaction in an online retail setting Paul", Journal of Service Management, Vol. 33 No. 6, pp. 461-471.

Bilińska-Reformat, K., Kucharska, B., Twardzik, M. and Dolega, L. (2019), "Sustainable development concept and creation of innovative business models by retail chains", International Journal of Retail and Distribution Management, Vol. 47 No. 1, pp. 2-18.

Bonetti, F., Warnaby, G. and Quinn, L. (2018), "Augmented Reality and Virtual Reality in Physical and Online Retailing: A Review, Synthesis and Research Agenda", in Jung, T. and tom Dieck, M.C. (Eds.), In Augmented Reality and Virtual Reality, Springer, Cham, Switzerland, pp. 119-132.

Brown, M. and Lubelczyk, M. (2018), The Future of Shopping Centers, Kearney, Chicago, available at: https://www.kearney.com/consumer-retail/article/?/a/thefuture-of-shopping-centers-article.

Brynjolfsson, E., Hu, Y.J. and Rahman, M.S. (2013), "Competing in the Age of Omnichannel Retailing", MIT Sloan Management Review, Vol. 54 No. 4, pp. 2329.

Burdick, A. (2018), "The marriage-saving robot that can assemble IKEA furniture, sort of", The New Yorker, available at: https://www.newyorker.com/science/labnotes/the-marriage-saving-robot-that-can-assemble-ikea-furniture-sort-of (accessed 1 April 2019).

Caboni, F. and Hagberg, J. (2019), "Augmented reality in retailing: a review of features, applications and value", International Journal of Retail \& Distribution Management, Vol. 47 No. 11, pp. 1125-1140.

Carroll, N. (2019), “Online Retailing - UK - July 2019 - Market Research Report”, Mintel.

Chaffey, D. (2017), "The reasons why consumers shop online instead of in stores | Smart Insights", Smart Insights, available at:

https://www.smartinsights.com/ecommerce/ecommerce-strategy/the-reasonswhy-consumers-shop-online-instead-of-in-stores/ (accessed 1 March 2019).

Chen, C.W.D. and Cheng, C.Y.J. (2009), “Understanding consumer intention in online shopping: A respecification and validation of the DeLone and McLean model", Behaviour and Information Technology, Vol. 28 No. 4, pp. 335-345.

Chesney, T., Chuah, S.-H., Dobele, A.R. and Hoffmann, R. (2017), "Information richness and trust in v-commerce: implications for services marketing", Journal 
of Services Marketing, Vol. 31 No. 3, pp. 295-307.

Chevalier, A. and Ivory, M.Y. (2003), "Web site designs: Influences of designer's expertise and design constraints", International Journal of Human-Computer Studies, Vol. 58, pp. 57-87.

Childers, T.L., Carr, C.L., Peck, J. and Carson, S. (2001), "Hedonic and utilitarian motivations for online retail shopping behavior", Journal of Retailing, Vol. 77 No. 4, pp. 511-535.

Coursaris, C.K., Swierenga, S.J. and Watrall, E. (2008), "An empirical investigation of color temperature and gender effects on web aesthetics", Journal of Usability Studies, Usability Professionals' Association, Vol. 3 No. 3, pp. 103-117.

Craven, M., Liu, L., Mysore, M. and Wilson, M. (2020), "COVID-19: Implications for business", McKinsey, available at: https://www.mckinsey.com/businessfunctions/risk/our-insights/covid-19-implications-for-business (accessed 1 April 2020).

Dacko, S.G. (2017), "Enabling smart retail settings via mobile augmented reality shopping apps", Technological Forecasting and Social Change, Elsevier Inc., Vol. 124, pp. 243-256.

Demangeot, C. and Broderick, A.J. (2010), "Consumer Perceptions of Online Shopping Environments", Psychology \& Marketing, Vol. 30 No. 6, pp. 461-469.

Demangeot, C. and Broderick, A.J.J. (2006), "Exploring the experiential intensity of online shopping environments", Qualitative Market Research: An International Journal, Vol. 9 No. 4, pp. 325-351.

Eastin, M.S. (2002), "Diffusion of e-commerce: an analysis of the adoption of four ecommerce activities", Telematics and Informatics, Elsevier, Vol. 19 No. 3, pp. 251-267.

Elliot, S. and Fowell, S. (2000), "Expectations versus reality: a snapshot of consumer experiences with Internet retailing", International Journal of Information Management, Elsevier, Vol. 20 No. 5, pp. 323-336.

Escobar-Rodríguez, T. and Bonsón-Fernández, R. (2017), "Analysing online purchase intention in Spain: fashion e-commerce", Information Systems and EBusiness Management, Vol. 15 No. 3, pp. 599-622.

Fornerino, M., Helme-Guizon, A. and Gotteland, D. (2008), "Movie consumption experience and immersion: impact on satisfaction", Recherche et Applications En Marketing (English Edition), SAGE Publications Sage UK: London, England, Vol. 23 No. 3, pp. 93-110.

Forni, A. and Meulen, R. (2016), "Gartner's 2016 Hype Cycle for Emerging Technologies Identifies Three Key Trends That Organizations Must Track to Gain Competitive Advantage", Stamford, Conneticut. Retrieved from http://www. gartner. com/newsroom/id/3412017.

Garnier, M. and Poncin, I. (2010), "To Be Or Not to Be? Virtual Experience and 
Immersion on a 3D Commercial Web Site", Advances in Consumer Research, Vol. 37, pp. 406-412.

Gaskin, S.P., Griffin, A., Hauser, J.R., Katz, G.M. and Klein, R.L. (2010), "Voice of the Customer", Wiley International Encyclopedia of Marketing, John Wiley \& Sons, Ltd, Chichester, UK, available at:https://doi.org/10.1002/9781444316568.wiem05020.

Grewal, D., Iyer, G.R. and Levy, M. (2004), "Internet retailing: Enablers, limiters and market consequences", Journal of Business Research, Vol. 57 No. 7, pp. 703713.

Holte, M.B. (2013), "Virtual Dressing Room: A Perspective on Recent Developments", International Conference on Virtual, Augmented and Mixed Reality, Springer Berlin Heidelberg, pp. 241-250.

Hope Allwood, E. (2016), "Is virtual reality the future of the fashion show?", Dazed, available at: http://www.dazeddigital.com/fashion/article/30163/1/is-virtualreality-the-future-of-the-fashion-show (accessed 31 January 2019).

Huang, M.-H. and Rust, R.T. (2018), "Artificial intelligence in service”, Journal of Service Research, SAGE Publications Sage CA: Los Angeles, CA, Vol. 21 No. 2, pp. 155-172.

Kang, H.J. (2017), "Designing next generation marketplace: The effect of 3D VR store interface design on shopping behavior", Proceedings - IEEE Virtual Reality, pp. 411-412.

Van Kerrebroeck, H., Brengman, M. and Willems, K. (2017), "When brands come to life: experimental research on the vividness effect of Virtual Reality in transformational marketing communications", Virtual Reality, Springer London, Vol. 21 No. 4, pp. 177-191.

Kim, J. and Forsythe, S. (2007), "Hedonic usage of product virtualization technologies in online apparel shopping", International Journal of Retail \& Distribution Management, Emerald Group Publishing Limited, Vol. 35 No. 6, pp. 502-514.

Kim, Y. (2002), "Consumer value: an application to mall and Internet shopping", International Journal of Retail \& Distribution Management, Vol. 30 No. 12, pp. 595-602.

Klein, L.R. (2003), "Creating virtual product experiences: The role of telepresence”, Journal of Interactive Marketing, Elsevier, Vol. 17 No. 1, pp. 41-55.

Meißner, M., Pfeiffer, J., Pfeiffer, T. and Oppewal, H. (2018), "Combining virtual reality and mobile eye tracking to provide a naturalistic experimental environment for shopper research", Journal of Business Research, Vol. [In Press], available at:https://doi.org/10.1016/j.jbusres.2017.09.028.

Munir, A., Barry, P. and Asma, D. (2016), "3D Servicescape Model: Atmospheric Qualities of Virtual Reality Retailing", International Journal of Advanced Computer Science and Applications, Vol. 7 No. 2, available 
at:https://doi.org/10.14569/IJACSA.2016.070204.

Newhagen, J.E., Cordes, J.W. and Levy, M.R. (1995), "Audience Scope and the Perception of Interactivity in Viewer Mail on the Internet", Journal of Communication, Vol. 45 No. 3, pp. 164-175.

Nielsen. (2016), "Reality Check: A Peek at the Virtual Audiences of Tomorrow", Nielsen, available at: https://www.nielsen.com/us/en/insights/article/2016/realitycheck-a-peek-at-the-virtual-audiences-of-tomorrow/ (accessed 1 April 2019).

Nielsen, J. (2000), "Why You Only Need to Test with 5 Users", Neilsen Norman Group, available at: https://measuringu.com/five-users/ (accessed 1 April 2019).

Nielsen, J. and Molich, R. (1990), "Heuristic evaluation of user interfaces", Proceedings of the SIGCHI Conference on Human Factors in Computing Systems, ACM, pp. 249-256.

Niemeier, S., Zocchi, A. and Catena, M. (2013), "A Call to Action", Reshaping Retail: Why Technology Is Transforming the Industry and How to Win in the New Consumer Driven World, Wiley and Sons Ltd., Chichester, UK.

Oculus. (2020), "Oculus Rift S", Oculus, available at: https://www.oculus.com/rift-s/ (accessed 1 April 2020).

Pantano, E., Priporas, C.V. and Dennis, C. (2018), "A new approach to retailing for successful competition in the new smart scenario", International Journal of Retail and Distribution Management, Vol. 46 No. 3, pp. 264-282.

Pantano, E. and Viassone, M. (2014), "Demand pull and technology push perspective in technology-based innovations for the points of sale: The retailers evaluation", Journal of Retailing and Consumer Services, Elsevier, Vol. 21 No. 1, pp. 43-47.

Papadopoulou, P. (2007), "Applying virtual reality for trust-building e-commerce environments", Virtual Reality, Vol. 11 No. 2-3, pp. 107-127.

Papagiannidis, S., Pantano, E., See-To, E.W.K., Dennis, C. and Bourlakis, M. (2017), "To immerse or not? Experimenting with two virtual retail environments", Information Technology \& People, Vol. 30 No. 1, pp. 163-188.

Park, M., Im, H. and Kim, D.Y. (2018), "Feasibility and user experience of virtual reality fashion stores", Fashion and Textiles, Springer Singapore, Vol. 5 No. 1, available at:https://doi.org/10.1186/s40691-018-0149-x.

Parker, C.J. and Wang, H. (2016), "Examining hedonic and utilitarian motivations for $\mathrm{m}$-commerce fashion retail app engagement", Journal of Fashion Marketing and Management, Vol. 20 No. 4, pp. 487-506.

Parker, C.J. and Wenyu, L. (2019), "What influences Chinese fashion retail? Shopping motivations, demographics and spending", Journal of Fashion Marketing and Management: An International Journal, Vol. 23 No. 2, pp. 158175. 
PwC. (2017), "Store openings at lowest level in seven years, as digital demands and appetite for experiences continue to redefine British high streets", PwC.

Al Qeisi, K.I. and Al-Abdallah, G.M. (2014), "Website design and usage behaviour: an application of the UTAUT model for internet banking in UK", International Journal of Marketing Studies, Vol. 6 No. 1, p. 75.

QSR. (2017), "NVivo 11”, QSR International, Melbourne, Australia.

Rese, A., Schreiber, S. and Baier, D. (2014), "Technology acceptance modeling of augmented reality at the point of sale: Can surveys be replaced by an analysis of online reviews?", Journal of Retailing and Consumer Services, Elsevier, Vol. 21 No. 5, pp. 869-876.

Sharma, S. and Bach, C. (2016), "An Exploratory Research on Virtual Reality and How it Affects Future of Shopping and Immerging Fields", European Journal of Engineering Research and Science, Vol. 1 No. 6, pp. 34-43.

Singhavolakul, N., Lee, T.-R. and Sinnarong, N. (2011), "Identifying types of stores in commercial zones and their marketing strategies", International Journal of Enterprise Network Management, Inderscience Publishers Ltd, Vol. 4 No. 3, pp. 275-301.

Skeldon, P. (2020), "65\% of UK consumers would change their shopping behaviour if retail outlets were more experiential", Internet Retailing, available at: https://internetretailing.net/mobile-theme/mobile-theme/65-of-uk-consumerswould-change-their-shopping-behaviour-if-retail-outlets-were-more-experiential20991 (accessed 1 April 2020).

Speicher, M., Cucerca, S. and Krüger, A. (2017), "VRShop”, Proceedings of the ACM on Interactive, Mobile, Wearable and Ubiquitous Technologies, Vol. 1 No. 3, pp. 1-31.

Thakur, R. (2018), "The role of self-efficacy and customer satisfaction in driving loyalty to the mobile shopping application", International Journal of Retail and Distribution Management, Vol. 46 No. 3, pp. 283-303.

The VR/AR Association. (2017), "Retail \& eCommerce Committee", The VR/AR Association Homepage, available at: https://www.thevrara.com/retailecommerce (accessed 31 January 2019).

Tode, C. (2017), "Are retailers ready for shift to virtual reality shopping?", Retail Dive, available at: https://www.retaildive.com/ex/mobilecommercedaily/are-retailersready-for-shift-to-virtual-reality-shopping (accessed 1 April 2020).

Trabelsi-Zoghlami, A. and Touzani, M. (2019), "How real are virtual experiences?: For a better understanding of virtual experiences and their impact on consumers' real life", European Journal of Marketing, available at:https://doi.org/10.1108/EJM-10-2017-0776.

Tseng, E.L. and Yazdanifar, R. (2015), "Mobility - The Revolutionary Change to Customer's Shopping Experience in Retailing", International Journal of Management, Accounting and Economics, Vol. 2 No. 9, pp. 1037-1048. 
Verhulst, A., Normand, J.-M., Lombart, C. and Moreau, G. (2017), "A study on the use of an immersive virtual reality store to investigate consumer perceptions and purchase behavior toward non-standard fruits and vegetables", 2017 IEEE Virtual Reality (VR), IEEE, pp. 55-63.

Vida 3D. (2015), "Trillenium Demo App - Vida 3D - YouTube", Youtube, available at: https://youtu.be/bNRnyR-Z-bQ (accessed 1 April 2019).

Vila, N. and Kuster, I. (2011), "Consumer feelings and behaviours towards well designed websites”, Information \& Management, Vol. 48 No. 4-5, pp. 166-177.

Vrechopoulos, A., Apostolou, K. and Koutsiouris, V. (2009), "Virtual reality retailing on the web: Emerging consumer behavioural patterns", International Review of Retail, Distribution and Consumer Research, Vol. 19 No. 5, pp. 469-482.

Walsh, K.R. (2002), "Reducing distance in e-commerce using virtual reality", EBusiness Handbook. St Lucie Press, Boca Raton.

Wang, H. (2016), "From Virtual Reality To Personalized Experiences: Alibaba Is Bringing Us The Future Of Retail This Singles Day", Forbes, available at: https://www.forbes.com/sites/helenwang/2016/11/06/how-alibaba-will-use-theworlds-biggest-shopping-day-to-transform-retail/ (accessed 23 August 2019).

Wang, Y.J., Minor, M.S. and Wei, J. (2011), "Aesthetics and the online shopping environment: Understanding consumer responses", Journal of Retailing, New York University, Vol. 87 No. 1, pp. 46-58.

Wolfinbarger, M. and Gilly, M.M.C. (2001), "Shopping Online for Freedom, Control, and Fun”, California Management Review, Vol. 43 No. 2, pp. 34-55.

Xue, L., Parker, C.J. and McCormick, H. (2018), "A Virtual Reality and Retailing Literature Review: Current Focus, Underlying Themes and Future Directions", in tom Dieck, Claudia, M. and Jung, T. (Eds.), Augmented Reality and Virtual Reality: The Power of AR and VR for Business, Springer International Publishing, Manchester, UK, pp. 27-41.

Yim, M.Y.C., Chu, S.C. and Sauer, P.L. (2017), "Is Augmented Reality Technology an Effective Tool for E-commerce? An Interactivity and Vividness Perspective", Journal of Interactive Marketing, Direct Marketing Educational Foundation, Inc. dba Marketing EDGE, Vol. 39, pp. 89-103.

Yoo, W.-S., Lee, Y. and Park, J. (2010), "The role of interactivity in e-tailing: Creating value and increasing satisfaction", Journal of Retailing and Consumer Services, Elsevier, Vol. 17 No. 2, pp. 89-96.

Zhou, L. (2007), "a Critical Survey of Consumer Factors in Online Shopping", Marketing Journal, Vol. 8 No. 1, pp. 41-62. 


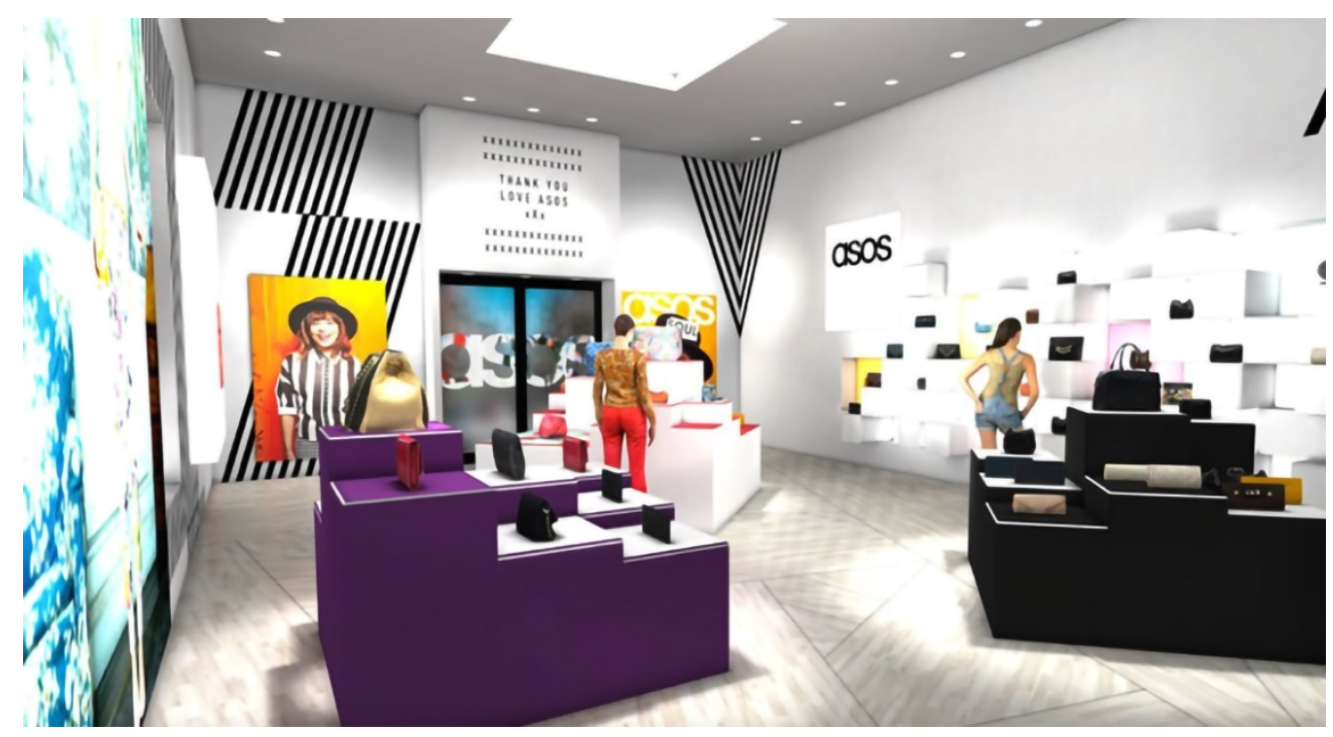

Figure 1. ASOS: Trillenium Demo App $99 \times 54 \mathrm{~mm}(300 \times 300 \mathrm{DPI})$ 


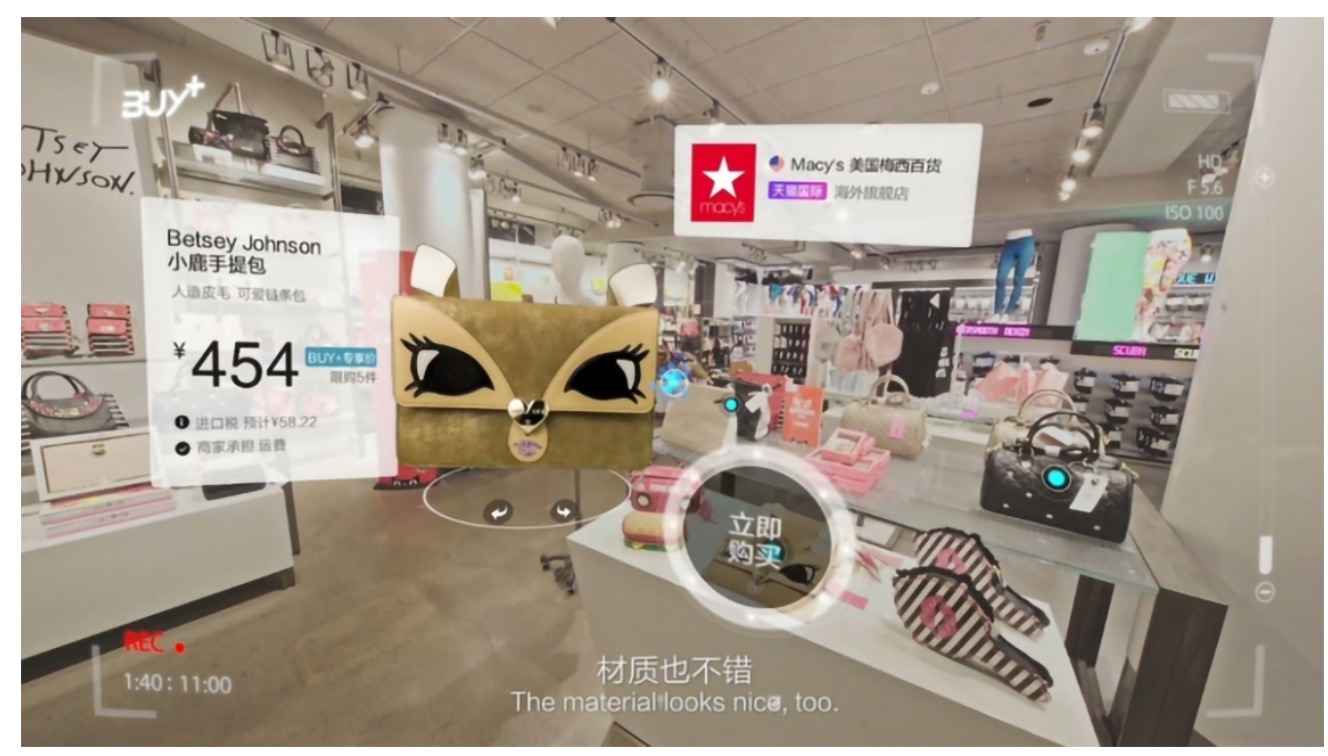

Figure 2. Buy+ The first complete VR shopping experience $99 \times 56 \mathrm{~mm}(300 \times 300 \mathrm{DPI})$ 


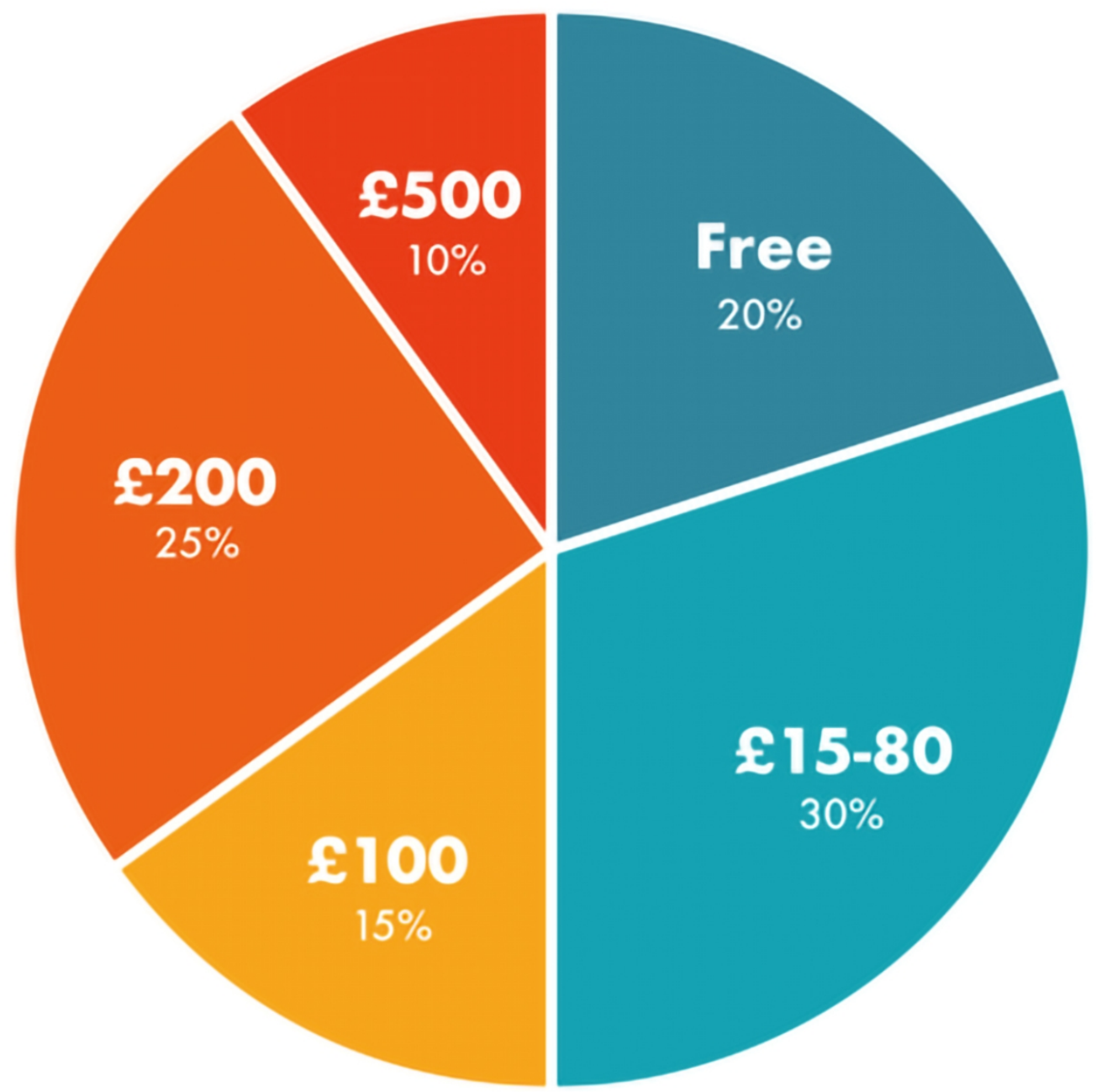

Figure 3. The percentage of participants based on the cost they are willing to spend on a VR headset $99 \times 99 \mathrm{~mm}(300 \times 300 \mathrm{DPI})$ 
Table 1. The Differences between VR and AR (Caboni and Hagberg, 2019)

\begin{tabular}{|l|c|c|}
\hline \multicolumn{1}{|c|}{ Differences } & VR & AR \\
\hline Reproduction in 3D & Environment & Objects \\
\hline Superposition & $\begin{array}{c}\text { Virtual objective in } \\
\text { virtual environment }\end{array}$ & $\begin{array}{c}\text { Virtual objective in real } \\
\text { environment }\end{array}$ \\
\hline $\begin{array}{l}\text { Need for electronic } \\
\text { tool }\end{array}$ & Yes & No \\
\hline Kind of reality & Synthetic reality & Natural reality \\
\hline
\end{tabular}


Table 2. The Category of Utilitarian and Hedonic Motivation (Parker and Wang, 2016)

\begin{tabular}{|l|l|l|}
\hline Motivation & \multicolumn{1}{|c|}{ Element } & \multicolumn{1}{c|}{ Aim } \\
\hline \multirow{4}{*}{ Utilitarian } & Efficiency Shopping & saving time or other related resources \\
\cline { 2 - 3 } & Achievement Shopping & goal-oriented, gaining a specific product \\
\hline \multirow{4}{*}{ Hedonic } & Gratification Shopping & $\begin{array}{l}\text { releasing stress or seeking individuals' } \\
\text { specific treatment }\end{array}$ \\
\cline { 2 - 3 } & Social Shopping & enjoying shopping with friends/family \\
\cline { 2 - 3 } & Value Shopping & $\begin{array}{l}\text { seeking discount/promotion or hunting } \\
\text { bargain }\end{array}$ \\
\cline { 2 - 3 } & Idea Shopping & collecting information of recent trends \\
\cline { 2 - 3 } & Role Shopping & selecting gift/goods for others \\
\cline { 2 - 3 } & Adventure Shopping & $\begin{array}{l}\text { shopping for excitement, simulation and } \\
\text { adventure }\end{array}$ \\
\hline
\end{tabular}


Table 3. Relevance Characteristics of VR in Interview - Coding References (Attitude and Motivation)

\begin{tabular}{|c|c|c|c|c|c|}
\hline Topic & Theme & Category & Themes from Data & $\begin{array}{l}\text { Participants } \\
\text { Aged 18-34 }\end{array}$ & $\begin{array}{l}\text { Participants } \\
\text { Aged 35-45 }\end{array}$ \\
\hline \multirow{26}{*}{$\begin{array}{l}\text { Attitude } \\
\text { Towards } \\
\text { V- } \\
\text { Commerce }\end{array}$} & \multirow{6}{*}{$\begin{array}{l}\text { Technology } \\
\text { Acceptance }\end{array}$} & \multirow[t]{2}{*}{ Positive } & \multirow{2}{*}{$\begin{array}{l}\text { Novelty effects } \\
\text { Benefit from VR }\end{array}$} & 13 & 4 \\
\hline & & & & 19 & 3 \\
\hline & & \multirow[t]{4}{*}{ Negative } & Expensive & 15 & 2 \\
\hline & & & Adaptation & 4 & 5 \\
\hline & & & $\begin{array}{l}\text { Change of shopping } \\
\text { behaviour }\end{array}$ & 0 & 5 \\
\hline & & & Technology awareness & 2 & 5 \\
\hline & \multirow{4}{*}{$\begin{array}{l}\text { Ease of } \\
\text { Use }\end{array}$} & Positive & Easy to use & 11 & 4 \\
\hline & & \multirow{3}{*}{ Negative } & Need time to adopt & 2 & 3 \\
\hline & & & Need training & 0 & 1 \\
\hline & & & Motion sickness & 1 & 1 \\
\hline & \multirow[t]{4}{*}{ Enjoyment } & \multirow[t]{3}{*}{ Positive } & Interact with people & 13 & 5 \\
\hline & & & Fictitious possibility & 2 & 1 \\
\hline & & & Being in another world & 3 & 1 \\
\hline & & Negative & No requirement & 3 & 2 \\
\hline & \multirow[t]{3}{*}{ Trust } & \multirow[t]{2}{*}{ Positive } & \multirow{2}{*}{$\begin{array}{l}\text { In the future, but not now } \\
\text { Better understanding of } \\
\text { a product }\end{array}$} & 3 & 1 \\
\hline & & & & 20 & 3 \\
\hline & & Negative & $\begin{array}{l}\text { Cannot replace online } \\
\text { shopping }\end{array}$ & 1 & 3 \\
\hline & \multirow{9}{*}{$\begin{array}{l}\text { Usefulness } \\
\& \\
\text { Functions }\end{array}$} & \multirow[t]{8}{*}{ Positive } & Product interaction & 30 & 7 \\
\hline & & & Social dimension & 26 & 4 \\
\hline & & & See exact items & 19 & 6 \\
\hline & & & $\begin{array}{l}\text { Product involvement \& } \\
\text { perception }\end{array}$ & 21 & 2 \\
\hline & & & Emulation shopping & 4 & 3 \\
\hline & & & Physical presence & 21 & 4 \\
\hline & & & Personalisation & 33 & 12 \\
\hline & & & Sales assistant & 11 & 2 \\
\hline & & Negative & $\begin{array}{l}\text { No significant } \\
\text { improvement }\end{array}$ & 2 & 3 \\
\hline \multirow{11}{*}{$\begin{array}{l}\text { Motivation } \\
\text { Towards } \\
\text { V- } \\
\text { Commerce }\end{array}$} & \multirow[t]{5}{*}{ Utilitarian } & \multirow[t]{3}{*}{ Positive } & $\begin{array}{l}\text { More aware about the } \\
\text { product }\end{array}$ & 20 & 3 \\
\hline & & & Quicker decision-making & 6 & 1 \\
\hline & & & Save efforts & 3 & 2 \\
\hline & & \multirow[t]{2}{*}{ Negative } & Waste time & 6 & 6 \\
\hline & & & Complex procedure & 2 & 1 \\
\hline & \multirow[t]{6}{*}{ Hedonic } & \multirow[t]{6}{*}{ Positive } & Being in a new place & 11 & 1 \\
\hline & & & Enjoyment & 10 & 2 \\
\hline & & & Social purpose & 5 & 1 \\
\hline & & & $\begin{array}{l}\text { Need advice (friends \& } \\
\text { sales assistants) }\end{array}$ & 17 & 8 \\
\hline & & & Follow the current trend & 7 & 2 \\
\hline & & & $\begin{array}{l}\text { Looking for something } \\
\text { interesting }\end{array}$ & 4 & 2 \\
\hline
\end{tabular}


Table 4. Relevance Characteristics of VR in Interview- Coding References (Influential Variables)

\begin{tabular}{|c|c|c|c|c|c|}
\hline Topic & Theme & Category & Themes from Data & $\begin{array}{l}\text { Participants } \\
\text { Aged 18-34 }\end{array}$ & $\begin{array}{l}\text { Participants } \\
\text { Aged 35-45 }\end{array}$ \\
\hline \multirow{18}{*}{$\begin{array}{l}\text { Inferential } \\
\text { Variables } \\
\text { Towards } \\
\text { V- } \\
\text { Commerce }\end{array}$} & \multirow[t]{4}{*}{ Comfort } & \multirow[t]{4}{*}{ Positive } & Convenience & 25 & 10 \\
\hline & & & Without crowding & 19 & 0 \\
\hline & & & Easy access & 17 & 1 \\
\hline & & & Relax & 4 & 2 \\
\hline & \multirow[t]{8}{*}{ Content } & \multirow[t]{3}{*}{ Environment } & $\begin{array}{l}\text { Authenticity (product } \\
\text { \& environment) }\end{array}$ & 26 & 8 \\
\hline & & & $\begin{array}{l}\text { Pleasant environment } \\
\text { (light \& sound) }\end{array}$ & 7 & 3 \\
\hline & & & Designed store layout & 9 & 4 \\
\hline & & \multirow[t]{3}{*}{ Information } & Consumer reviews & 14 & 7 \\
\hline & & & Easy navigation & 8 & 6 \\
\hline & & & Quality information & 5 & 3 \\
\hline & & $\begin{array}{l}\text { Product } \\
\text { Display }\end{array}$ & $\begin{array}{l}\text { Clear and ordered } \\
\text { product display }\end{array}$ & 2 & 4 \\
\hline & & Product feature & Vividness & 12 & 7 \\
\hline & \multirow[t]{6}{*}{ Functionality } & Accessibility & Simple procedure & 11 & 4 \\
\hline & & Interactivity & $\begin{array}{l}\text { Interact with product } \\
\text { and people }\end{array}$ & 11 & 3 \\
\hline & & Media richness & $\begin{array}{l}\text { Cannot touch the } \\
\text { product }\end{array}$ & 10 & 3 \\
\hline & & \multirow[t]{3}{*}{ Personalisation } & Personal service & 12 & 6 \\
\hline & & & $\begin{array}{l}\text { Personalised } \\
\text { interface }\end{array}$ & 14 & 5 \\
\hline & & & $\begin{array}{l}\text { Product } \\
\text { recommendation }\end{array}$ & 7 & 1 \\
\hline
\end{tabular}


Table 5. V-Commerce's 13 Design Requirements

\begin{tabular}{|c|c|c|c|}
\hline Theme & Design Aim & VR Solution & Business Impact \\
\hline \multirow[t]{3}{*}{ Accessibility } & $\begin{array}{l}\text { Reduce } \\
\text { technology } \\
\text { acceptance } \\
\text { barriers }\end{array}$ & $\begin{array}{l}\text { 1. Develop eye-tracking functions } \\
\text { 2. Include disadvantages consumers' } \\
\text { considerations }\end{array}$ & $\begin{array}{l}\text { Increase } \\
\text { consumer base }\end{array}$ \\
\hline & $\begin{array}{l}\text { Ease the need for } \\
\text { older audiences } \\
\text { to change current } \\
\text { shopping } \\
\text { behaviour }\end{array}$ & $\begin{array}{l}\text { 3. Offer easy accessibility/ usability } \\
\text { (hand and head movements that } \\
\text { must conform to the daily } \\
\text { behavioural logic) }\end{array}$ & $\begin{array}{ll}\text { Encourage } \\
\text { consumers } \\
\text { motivation } \\
\text { Bring new } \\
\text { entrants }\end{array}$ \\
\hline & $\begin{array}{l}\text { Reduce } \\
\text { consumer } \\
\text { perception of } \\
\text { price }\end{array}$ & $\begin{array}{l}\text { 4. Offer loyal consumers VR } \\
\text { accessories as gifts or loan items } \\
\text { when they purchase }\end{array}$ & $\begin{array}{l}\text { Increase } \\
\text { spending from } \\
\text { existing } \\
\text { consumers }\end{array}$ \\
\hline \multirow[t]{2}{*}{ Functionality } & $\begin{array}{l}\text { Improve } \\
\text { consumers' } \\
\text { perception } \\
\text { towards v- } \\
\text { Commerce }\end{array}$ & $\begin{array}{l}\text { 5. Offer efficient search engine, } \\
\text { handy features (guidance system, } \\
\text { product recommendation and } \\
\text { product comparison etc.) } \\
\text { 6. Offer a streamlined purchase } \\
\text { procedure }\end{array}$ & $\begin{array}{l}\text { Improve } \\
\text { consumers' } \\
\text { perception } \\
\text { towards v- } \\
\text { Commerce }\end{array}$ \\
\hline & $\begin{array}{l}\text { Meet different } \\
\text { motivations }\end{array}$ & $\begin{array}{l}\text { 7. Offer a different mode for both } \\
\text { hedonic and utilitarian consumers } \\
\text { 8. Empower consumers to control } \\
\text { over entertainment functions (i.e. } \\
\text { Social interaction, adventure } \\
\text { shopping experience, background } \\
\text { music, lighting etc.) }\end{array}$ & $\begin{array}{ll}\cdot & \text { Increase } \\
\text { consumers' } \\
\text { satisfaction } \\
\text { Increase } \\
\text { consumer } \\
\text { loyalty }\end{array}$ \\
\hline \multirow[t]{2}{*}{$\begin{array}{l}\text { Assistant } \\
\text { System }\end{array}$} & $\begin{array}{l}\text { Increase product } \\
\text { perception }\end{array}$ & $\begin{array}{l}\text { 9. Offer intelligence sales assistant to } \\
\text { provide product and product- } \\
\text { related information }\end{array}$ & $\begin{array}{ll} & \text { Increase overall } \\
& \text { profit. }\end{array}$ \\
\hline & $\begin{array}{l}\text { Enhance human } \\
\text { contact }\end{array}$ & $\begin{array}{l}\text { 10. Enable consumers to book } \\
\text { shopping time with the seller, } \\
\text { where consumers can interact with } \\
\text { physical salesperson via video call } \\
\text { for more flexible requirements } \\
\text { within the specific time slot (ask for } \\
\text { showing real product, personal } \\
\text { advice, etc.) }\end{array}$ & $\begin{array}{ll}\text { - } & \text { Increase } \\
& \text { consumer } \\
& \text { loyalty } \\
\text { - } & \text { Increase profit. }\end{array}$ \\
\hline \multirow[t]{3}{*}{$\begin{array}{l}\text { Content } \\
\text { Design }\end{array}$} & $\begin{array}{l}\text { Attract } \\
\text { consumers }\end{array}$ & $\begin{array}{l}\text { 11. Surpass physical stores' content } \\
\text { designs - enable consumers } \\
\text { experience events they couldn't do } \\
\text { in the real-world environment }\end{array}$ & $\begin{array}{ll}\text { - } & \text { Appeal new } \\
\text { consumer } \\
\text { - } \\
\text { Retain existing } \\
\text { consumer } \\
\text { group. }\end{array}$ \\
\hline & $\begin{array}{l}\text { Increase } \\
\text { consumers' trust } \\
\text { in v-Commerce }\end{array}$ & $\begin{array}{l}\text { 12. Offer lifelike interactions (giving } \\
\text { authentic environments rather than } \\
\text { stylised interfaces and the realistic } \\
\text { size and colour of the products) }\end{array}$ & $\begin{array}{ll} & \text { Increase } \\
& \text { stakeholder } \\
& \text { value } \\
\text { - } \quad \text { Increase profit. }\end{array}$ \\
\hline & $\begin{array}{l}\text { Meet consumers' } \\
\text { social needs and } \\
\text { improve }\end{array}$ & $\begin{array}{l}\text { 13. Offer social dimension and virtual } \\
\text { community - enable consumers to }\end{array}$ & $\begin{array}{l}\text { Enhance } \\
\text { consumer } \\
\text { loyalty }\end{array}$ \\
\hline
\end{tabular}


